\section{Windbreaks: An Important Component in a Plasticulture System}

\section{Laurie Hodges ${ }^{1}$ and James R. Brandle ${ }^{2}$}

Additional index words. shelterbelt, environment, wind stress, vegetable production

Summary. Windbreaks reduce wind speed and modify the microclimate in sheltered areas. Many producers use wind barriers in their production systems, but few producers recognize all of the benefits available or understand the principles involved in windbreak function and design. Wind has direct and indirect effects on plant growth and development. Direct effects include soil abrasion, increased transpiration, and lodging. Indirect effects are based on changes in the crop microclimate, which influence plant growth and yield. Windbreaks increase soil and air temperatures and can extend the growing season in sheltered areas, resulting in increased crop development, earlier crop maturity, and market advantage. Plant-water relations and irrigation efficiency are improved by shelter. Overall, modifications to the microclimate in sheltered areas contribute to $5 \%$ to $50 \%$ higher crop yields. Winds in

${ }^{1}$ Department of Horticulture, University of NebraskaLincoln 68583-0724.

${ }^{2}$ Department of Forestry, Fisheries, and Wildlife, University of Nebraska-Lincoln 68583-0814.

University of Nebraska, Agricultural Research Division, journal series paper no. 11407. The use of trade names in this publication does not imply endorsement by the Agricultural Research Service of Nebraska of the products named, nor criticism of similar ones not mentioned.

The cost of publishing this paper was defrayed in part by the payment of page charges. Under postal regulations, this paper therefore must be hereby marked advertisement solely to indicate this fact.

excess of about $5 \mathrm{~m} \cdot \mathrm{s}^{-1}\left(1.0 \mathrm{~m} \cdot \mathrm{s}^{-1}=2.25\right.$ miles $/ \mathrm{h}$; miles $/ \mathrm{h} \times 0.447=\mathrm{m} \cdot \mathrm{s}^{-1}$ ) result in wind erosion and soil abrasion and may cause a loss of crop stand. Wind speeds below $5 \mathrm{~m} \cdot \mathrm{s}^{-1}$ may have an equally adverse impact on crop quality and marketable yield. In both cases, windbreaks can reduce damage effectively in sheltered areas. Wind protection reduces certain problems associated with plasticulture under windy conditions.

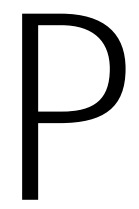

lasticulture is an intensive system of vegetable production in which technology is used to control and enhance crop growth. Plastic mulch protects fruit and leaves from direct contact with soil and controls weeds. When combined with drip irrigation and fertigation, it allows application of water and nutrients precisely calibrated for the specific crop and stage of growth.

Earlier production is probably the greatest benefit of growing crops using plastic mulch. Plastic mulch raises soil temperatures, increasing the rate of plant growth and development. Soil temperature under black plastic mulch can increase as much as $5^{\circ} \mathrm{C}$, measured $5 \mathrm{~cm}$ deep. Clear plastic mulch can increase soil temperatures as much as 8 to $9^{\circ} \mathrm{C}$. Plants reach maturity from 7 to 21 days earlier when grown with plastic mulch (Foskett, 1955; Lamont, 1993). This earlier harvest often increases market advantage and financial returns.

Other factors also have an impact on plant growth, yield, and quality. One factor often overlooked is the wind. Although the use of wind barriers is a common practice in horticultural production, the reasons for including windbreaks in plasticulture systems, as well as other impacts of the windbreak system, often are not understood by producers.

\section{Windbreak effects on microclimate}

The reduction of wind velocity by wind barriers has many ramifications in themicroclimate of the protected zone. Soil warming is one benefit of using either temporary or permanent windbreaks. Characteristically, air aboveasheltered crop is 1 to $2^{\circ} \mathrm{C}$ warmer than aboveacomparable, unsheltered area, a temperature increase sufficient to extend the growing season about 10 days (Grace, 1988; VanGardingen and Grace, 1991). Average hourly air temperature under sheltered conditions tends to be warmer during the day and cooler at night. This contributes to enhanced net assimilation rates and theincreased growth in sheltered areas (Brown and Rosenberg, 1972). It also contributes to more rapid growth during the spring and fall when air temperatures are cooler. Some growers express concern that the calmer air in sheltered zones may be conducive to frost formation. In our experience in Nebraska, the warmer soil in fields protected by tree windbreaks has reduced the incidence and severity of radiation frost injury to fall vegetables compared to vegetables growing in nearby exposed locations (personal observation).

Along with temperature, modification of plant-water relations is a major impact of wind reduction (Bilbro and Fryrear, 1988). Higher soil moisture is attributed to a reduction in direct evaporation (Sturrock, 1984). Although the total volume of water used may be greater for sheltered plants due to larger plant size, the water-use efficiency generally is improved over that of plants exposed to wind (Davis and Norman, 1988; Miller et al., 1974; Rosenberg et al., 1983). In temperate climates, permanent windbreaks contribute to increased soil moisture in the sheltered zone by trapping snow. The higher relative humidity characteristic of sheltered zones, especially those protected by vegetative windbreaks, may enhance plant growth, fruit set, and fruit quality factors, especially in arid or semi-arid climates. Research indicates that species respond differently to relative humidity, independent of temperature, for vegetativeand reproductivegrowth (Bakker, 1988; Lipton, 1970a, 1970b).

Overall, modifications to themicroclimatein sheltered areas contribute to $5 \%$ to $50 \%$ higher yields (Baldwin, 1988). In Nebraska, yields from small plots located in the zone from 1 to $3 \mathrm{H}$ from tree windbreaks ( $\mathrm{H}$ equals the height of the windbreak) were higher by $14 \%$ to $18 \%$ for cabbage, $13 \%$ to $100 \%$ for snap beans, and gave higher early yield in muskmelon (Brandle et al., 1995).

\section{Effects of wind on plants}

Wind has direct and indirect effects on plant growth. Most people associate wind damage with the direct mechanical effects of wind on plants, although the indirect effects on altered microclimate and associated changes in flora and fauna can have a great effect on yield. The benefit of shelter on crop growth and yield has been shown for many crop species throughout the world (Baldwin, 1988). However, the magnitude of the effect is variable, and the response mechanisms are understood only partly. VanGardingen and Grace (1991) attribute this, at least in part, to the many ways wind affects biological processes, and to the fact that any change in wind speed will be accompanied by other changes in microclimate, which also affect plant growth. In addition, the degree of benefit or the severity of damage is a function of crop species and growth stage, seedlings and reproductive stages being the most sensitive. Lodging can be a problem when heavy rains coincide with strong winds late in the season and plants are heavy with fruit.

Wind stress affects plant morphology, resulting in smaller, more compact plants with a 
higher root : shoot ratio than nonstressed plants (Biddington, 1985). Plants respond to thephysical motion of wind by altering growth patterns to increase the mechanical strength of various plant parts. Two types of wind events must be considered: gusts and mean daily winds. The morphological response of crop plants depends more on the intermittent and turbulent nature of wind than on the mean daily wind speed (VanGardingen and Grace, 1991), and the exposure time necessary to induce these responses may be very low, in some cases 30 s or less (Biddington, 1985; Jaffe, 1976; VanGardingen and Grace, 1991). As wind speeds increase, direct damage by wind becomes more of a problem. In much of the United States, wind speeds of 10 to $20 \mathrm{~m} \cdot \mathrm{s}^{-1}\left(1.0 \mathrm{~m} \cdot \mathrm{s}^{-1}=2.25 \mathrm{miles} / \mathrm{h}\right.$; miles $/ \mathrm{h} \times 0.447=\mathrm{m} \cdot \mathrm{s}^{-1}$ ) occur periodically during the growing season, either due to passing storms or weather fronts. There is considerable literature documenting the damage to growing crops that occurs with wind speeds in this range (Baldwin 1988; Grace, 1988; VanGardingen and Grace, 1991). Under these conditions, windbreaks provide significant protection, reducing wind speeds by $50 \%$ or more.

Vegetables have avery low tolerance to wind stress. The critical threshold wind speed for specific vegetable crops, or that wind speed above which vegetable crop yields are reduced, has not been well established. However, taken as a group, vegetables generally are listed in the most-sensitive or low-tolerance category compared to other crops (Finch, 1988). Limited research indicates that wind speeds of 4 to $5 \mathrm{~m} \cdot \mathrm{s}^{-1}$ can have physiologically harmful effects on many vegetables (Baldwin, 1988; Finch, 1988; Lin et al., 1987). Theseinclude serious disruption of the plant water balance, suppression of growth, lower photosynthetic efficiency, and adverse impact on pollination and fruit maturation. There is some indication that crops grown for the vegetative parts, such as cabbages, may be more sensitive to wind stress than plants grown for their reproductive tissues (Waister, 1972b; Winter, 1965). In contrast, many of the grain crops used as temporary windbreaks are among the more tolerant crops listed by Finch (1988).

According to NOAA (1983), more than $50 \%$ of the winds in the continental United States exceed $3.5 \mathrm{~m} \cdot \mathrm{s}^{-1}$ and $20 \%$ exceed $5.8 \mathrm{~m} \cdot \mathrm{s}^{-1}$, typically measured at $10 \mathrm{~m}$ height. Fortunately, wind slows as it approaches the surface due to surface friction and, as a result, wind speeds near the surface are generally less than $4 \mathrm{~m} \cdot \mathrm{s}^{-1}$. At these lower wind speeds, direct wind damage is low and the benefit of shelter may not be as obvious without a direct comparison to an equivalent unsheltered site.

Vegetable and other specialty crops are very sensitive to abrasion by wind-blown soil. As soil flux, wind velocity, or exposuretimeincrease, crop survival, growth, and yield decrease (Fryrear and Downs, 1975b). For the most erosive soils, the threshold wind velocity for soil movement is be- tween 3 and $4 \mathrm{~m} \cdot \mathrm{s}^{-1}$ (Woodruff et al., 1972; Zachar, 1982). Abrasion by larger particles from soil saltation and soil creep may injure plants close to the soil line. Physical abrasion, either by soil particles or plant parts rubbing together, reduces crop stand and decreases yield and crop quality from the remaining plants. In some cases, crops may need to be replanted, resulting in delayed harvest or, occasionally, in complete loss of a crop to an early frost. Since crop quality is a primary factor in the price received for the product, most vegetable and specialty crops benefit from extensive wind protection systems.

The greater sensitivity of young plants to soil abrasion is recognized (Armbrust, 1984; Liptay, 1987). Survival of tomato transplants from sandblast injury increased as the transplant root volume increased (up to $35 \mathrm{~cm}^{3}$ ) or the ageof the transplant increased up to 7 weeks (Liptay, 1987). Wemay assumethat this al so is truefor theindirect effects of lower wind speeds on stand establishment and flowering.

In most of the major vegetable production areas in the United States, concern with wind and/ or wind-blown soil is greatest during the early spring when stand establishment coincides with seasonally high winds and large areas of exposed soil during field preparation. Vegetable producers need to be especially aware of the problems associated with wind erosion since the soil characteristics that favor production are the same as those typical of erosive soils. Vegetable operations frequently are located on well-drained sandy soils or highly organic soils such as muck soils. Sandy soils are favored for early-season planting and the use of plasticulture, since they warm up earlier in the spring and the benefits of plastic mulch are supplemented by natural soil warming. However, these same soils tend to dry out quickly and, thus, are subject to erosion.

Soil loss and abrasion are not the only costs of wind erosion to vegetable producers. When winds erode soil during field preparation and planting, herbicides and nutrients that have be applied to the surface are lost. Hagen and Lyles (1985) estimated that the soil blown from a field may contain 10 to 20 times the organic matter and phosphates as the heavier particles that remain.

Crops that have an indeterminate growth pattern, such as cucumbers, or produce multiple flowers, such as beans, may be better able to compensate for losses caused by wind erosion than determinate crops such as cabbage, carrots, or onions (Fryrear and Downs, 1975a, 1975b). Carrots, peppers, and tomatoes were extremely susceptible to sand injury, whereas southern peas could withstand about five times more abrasion injury than carrots (Fryrear and Downes, 1975a, 1975b).

Soil particles carried by the wind, or plant parts rubbing against each other as the plant moves with the wind, can disrupt the cuticular layer on the leaf. As a result, transpiration in- creases and, if the leaf epidermis is damaged, water losses from the plant can be very large. The physical abrasion of leaf on leaf may disrupt the normal vapor barrier, but this is difficult to separatefrom the effects of changes in the microclimate on water use. The damaged cuticle also can predispose the leaf to pollution stress (VanGardingen and Grace, 1991) or invasion by pathogens (Claflin et al., 1973; Kahn et al., 1986; Pohronezhy et al., 1992).

\section{Wind, crop disease, and insects}

Windblown soil can carry inoculum for bacterial and fungal diseases (Claflin et al., 1973; Kahn et al., 1986; Pohronezhy et al., 1992) as well as wound plant tissues providing entry points for pathogens, especially bacteria. Shelter from wind and wind-blown soil may reducetheincidenceand severity of crop diseases. For example, Claflin et al. (1973) found that common blight of bean [Xanthomonasphaseoli(E.F.Sm.) Dows] increased $120 \%$ when the duration of exposure to windblown infested river sand increased from 3 to 5 min. Similarly, pepper plants injured by sandblast, or leaves subjected to wind abrasion by rubbing together, were significantly more susceptible to bacterial spot, developing twice the number of lesions as plants not subjected to wind stress. Wind velocity $\left(8 \mathrm{~m} \cdot \mathrm{s}^{-1}\right)$ and duration (5 to $10 \mathrm{~min}$ ) in this study were typical of the gusty winds in late summer storms (Pohronezhy et al., 1992). Wind scab on 'French' prune(Prunus domestica), caused by wind abrasion, increased infection by pathogens resulting in lost marketableyields equivalent to those caused by russet scab (Michailides and Morgan, 1993). In New Zealand, the economic benefits of wind protection for horticultural crops are at least equal to those of pest and disease control (Sturrock, 1984).

Windbreaksinfluencethedistribution of both crop pests and their natural enemies. In addition, more pollinating insects are found in sheltered areas. For example, bee flight is inhibited at wind speeds of 6.7 to $8.9 \mathrm{~m} \cdot \mathrm{s}^{-1}$ (Norton, 1988). Windbreaks also can reduce damage associated with aphid-transmitted viruses (Simons, 1957). For a completediscussion of insect distribution in shelter, see Pasek (1988).

\section{Windbreak design}

A windbreak provides two zones of protection, one to the leeward, which extends for a distance of roughly $10 \mathrm{H}$, and a smaller one to the windward extending about 1 to $3 \mathrm{H}$. Although wind speed reduction may extend as much as 20 to 25 Hto theleeward, maximum reductions occur within the zone from 3 to $6 \mathrm{H}$. The extent of the protected zone depends on the height and density of the windbreak. The density depends on the structure of the vegetation and the width of the barrier. A single row windbreak may provide adequate wind 
protection, but the potential for gaps forming from losses within the row usually favors multiple rows for vegetativewindbreaks. Windbreaks with densities of $40 \%$ to $60 \%$ provide the greatest combined benefits of wind reduction and protected zone (Finch, 1988).

For example, when using a 1-m-tall ryestrip, the zone of maximum protection extends roughly $10 \mathrm{~m}$, or the distance of six to seven beds on 1.5$\mathrm{m}$ centers. Similarly, when the rye is young, perhaps planted when the beds were formed and only 1 to 2 weeks before transplanting seedlings, the protection zone would be less; e.g., rye $15 \mathrm{~cm}$ tall would providemaximum wind protection for $1.5 \mathrm{~m}$ or the distance of one bed.

\section{Types of windbreaks}

Windbreaks can take many forms, including individual plant protectors, plastic row covers, plastic or wood slat fences, raised beds, annual and perennial crops, herbaceous perennial plants, shrubs, and trees. These provide varying degrees of wind protection, and each has advantages and disadvantages within a specific production system. Three major types are discussed.

Annual herbaceous windbreaks. Annual herbaceous windbreaks are relatively easy to install, inexpensive, grow quickly, and are compatible with overhead irrigation systems. They allow greater flexibility in farming operations than either artificial windbreaks, such as snow fences, or perennial windbreaks, such as trees and shrubs. Annual barriers can be moved or removed as necessary. Small grains such as rye (Secale cereale L.) or winter wheat (Triticum aestivum $\mathrm{L}$ ) frequently areused in plasticulturesystems to protect vegetable crops from wind stress and soil abrasion. Corn (ZeamaysL.) is also effective, although somewhat less tolerant of wind stress than either rye or winter wheat (Finch, 1988). These temporary or seasonal windbreaks often are established at the time the plasticulture bed is prepared by omitting the plastic every five to six rows or every 7 to $10 \mathrm{~m}$. Usually the grain is planted at the time of bed formation, all owing several weeks for growth before transplanting.

In mild climates, rye may be planted in the fall with additional starter fertilizer to promoteearly growth and a good, thick stand. These fall plantings provide greater wind protection to vegetables planted early in the spring such as cole crops or onions. Rye also can be planted across the entire field the previous fall or in the early spring, before laying plastic. However, it is recommended that the rye be killed early enough so that the debris in the beds does not interfere with fumigation or laying of plastic. Often grain is mowed when it begins to head to reducevolunteer grain in rotation crops. The mowed rows then are used as drive rows or utility rows for crop maintenance and harvesting.

In some parts of the United States, small grain is used as a winter cover crop to reduce winter wind erosion and nitrogen leaching. The grain cover crop is tilled under in the early spring, beforeplanting thevegetablecrop and early enough for decomposition to occur (Lanterman et al., 1985). Strips are left in the field at intervals of 15 to $20 \mathrm{~m}$ and are allowed to develop to maximum height and serve as windbreaks. Some growers remove strips of grain with shielded sprays of nonselective herbicides such as paraquat, glyphosate, sethoxydim (Poast), or fluazifop (Fusilade) rather than till them under during field preparation (Lanterman et al., 1985; Zandstra and Warncke, 1993). Regardless of how it is formed, the herbaceous windbreak should be established early enough to provide adequate protection to the seedling or transplanted crop. One major limitation to the use of herbaceous annual barriers is that weather conditions may limit the growth of the barrier and thus limit the effectiveness of the barrier during the early growing season.

An area of considerable interest is the use of mixed grass and legume strips as windbreaks in vegetable production. The legume crop increases the density and roughness factor of the windbreak strip while providing greater habitat diversity for beneficial insects (Bugg et al., 1991). Concomitantly, the vegetative windbreak may serve as a host to pest insects. The dynamic management of a vegetative windbreak to enhance the physical and biological components of an agro-ecosystem is poorly understood at this time and requires multidisciplinary approaches to derive practical and efficient production systems.

Concepts important to management of the arthropod component werereviewed by Bugg (1992) and for the vegetation by Phatak (1992). For example, ryemay serveas ahost to certain aphids early in the season, which in turn attract lady beetles (Coccinellidae) and parasitic wasps that also may attack vegetable insect pests (Bugg, 1992). Lady beetles movefrom senescent wheat to other crops in search of prey (Maredia et al., 1992); this may be analogous to the destruction of grain windbreaks in aplasticulturesystem with subsequentinsectmovement to vegetables, although this has not been documented experimentally. If ryestrips arekilled or mowed, the residue has important implications in soil and water conservation and may suppress weeds through alleopathicinteractions (Phatak, 1992). The potential dual use of vegetative strips as windbreaks and as insectary strips is an exciting and complex area of investigation.

When selecting plants for use as annual windbreaks, thegeneral recommendations arethat thedensity of thebarrier should be $50 \%$ to $60 \%$ for crop production benefits. Rows should beoriented perpendicular to the predominantdirection of erosive winds. If there is no predominant wind direction, the rows should be planted closer together, either on the contour or in aserpentinepattern. The plants selected should be relatively resistant to lodging and spaced for maximum effectiveness.
Generally, multiple rows are planted at 10- to 15$\mathrm{H}$ increments across the field. This reduces the number of rows subject to competition. One exception is noted. Beste (1986) found that strips of small grain 15 to $30 \mathrm{~cm}$ wide, planted between each pair of rows of vine crops, formed more effective windbreaks than $3 \mathrm{~m}$ wide strips planted 18 to $24 \mathrm{~m}$ apart. The grain was allowed to grow 0.5 to $1 \mathrm{~m}$ tall to increasewind protection and then was killed selectively with either sethoxydim or fluzazifop to suppress grain seed development and reduce intercrop competition. Additional research on various combinations and configurations is warranted, and producers should experiment with various spacings to determinethe best solution for their operation.

Perennial windbreaks. Windbreaks of perennial plants such as trees or shrubs, and in some cases perennial grasses, can be used singularly or in combination with annual windbreaks distributed across the crop field. Trees and shrubs al ong riparian corridors often providevaluable, yet overlooked, benefits in wind reduction. Perennial grass barriers function in the same manner as annual herbaceous barriers and therefore are not discussed in detail. They offer one distinct advantage over annual barriers in that they provide protection during the winter and early in the growing season. The remainder of this discussion focuses on traditional tree and shrub barriers.

The two major advantages of tree windbreaks are height and longevity. With protection on the leeward and windward side of a windbreak, the sheltered zone between two parallel windbreaks can extend for 100 to $150 \mathrm{~m}$ or more. While it may take 10 to 20 years for a tree windbreak to reach its matureheight, most treewindbreaks have a life span of more than 50 years. Thus, once established, tree windbreaks provide protection throughout the year and for a number of years.

The major disadvantages of tree windbreaks include the time necessary to reach a mature height and the degree of competition with an adjacent crop. Using a combination of annual barriers within a backbone of tree windbreaks, a producer can achieve immediate protection while investing in a long-term solution. Careful selection of tall, deep-rooted tree species and use of the zone next to the tree row for field access can minimize the area devoted to the windbreak and reduce the amount of competition to a level more than compensated for by the increase in yield and quality on the protected acres. With as little as $1 \%$ to $5 \%$ of the land base devoted to windbreaks, a producer can protect a crop, improve yield and quality, and increase profitability (Brandle et al., 1992, 1995).

Artificial windbreaks. Snow fences and various paper or plastic barriers are noncompetitive wind barriers, which, depending on the design, may beinstalled each year or be morepermanent. Artificial windbreaks are used on the edges of annual crops or as strips through the planting, 
spaced through the field similar to annual grain windbreaks. If large permanent wind screens are used, the design should include access for farm equipment and consideration of the characteristics of the equipment used to manage the crops. Artificial windbreaks offer theadvantages of lack of competition for water or nutrients with the crop rows immediately adjacent to the windbreaks.

Higher yields and changes in microclimate comparable to those achieved with vegetativewind barriers have been recorded. Bagley and Gowen (1960) found significantly higher yields related to shelter of snapbeans (37\%) and tomatoes (30\%). Monetteand Stewart (1987) investigated the effect of a plastic windbreak $1.5 \mathrm{~m}$ high on bell pepper yields at distances of 3 to $30 \mathrm{H}$ in the lee of the windbreak. Peppers were grown with and without perforated black plastic mulch. In a dry year, pepper fruit numbers were improved by shelter although no improvement was found during the following year with more moisture. Mulching gave higher yields than windbreak protection, but only in unsheltered conditions (Monette and Stewart, 1987). In Canada, plastic fiber windbreaks of different porosities gave $4.5 \mathrm{t} \cdot \mathrm{ha}^{-1}$ higher potato yields when wind speeds were reduced by $50 \%$ to $60 \%$ of the of the control (Bégin et al., 1994). Marketableyield of carrots werehigher when grown in the protected zone behind a plastic windbreak, and exhibited improved vitamin, color, and sensory attributes, which correlated with proximity to the windbreak (Taksdal, 1992). Even reductions in relatively low average wind speeds can give significantly higher yields. For example, strawberry yields were higher by an average of $56 \%$ over a 3 year period when mean wind speeds were reduced $31 \%$ from 1.6 to $1.1 \mathrm{~m} \cdot \mathrm{s}^{-1}$ using plastic mesh screens (Waister, 1972a). However, Harrison and Chrimes (1988) using 3.5-m-high, four-square enclosures of $50 \%$ permeablewood slat fences for wind protection of trellised runner beans found significantly higher yields only in years when strong winds occurred during the growing season. Average wind speed reduction due to shelter was $50 \%$. Although significantly higher total yields were inconsistent from year to year, quality of Class I beans was higher from the protected plants and produced a significantly higher calculated gross market value (more than $\$ 774$ per acre). Makus (1989) found a significantcorrelation be tween a 52\% reduction in wind speed using an artificial barrier and higher yields of the combined U.S. Fancy and U.S. No. 1 fruit for field-grown, trellised cucumbers. The higher grades were due primarily to reduced skin abrasion of the fruit.

Wind protection also can be achieved with continuous plastic row covers, which are most noted for their effects on soil and air temperature and, to a lesser extent, on wind and sandblast protection. The use of plastic row covers in specialty crop production has developed rapidly since the 1960s. Wells and Loy (1993) reviewed the use of row covers to enhance crop production, includ- ing the role of row covers for wind protection. Use of field windbreaks, either annual or perennial, can reduce wind damage to the plastic covers while also providing higher soil and air temperatures and reducing evaporation from the soil, thereby maintaining higher soil moisture.

\section{Conclusion}

Windbreaks reduce wind speed and improve microclimate in the sheltered zones. They provide many direct benefits to the producer while maximizing the ecological benefits of ecosystem diversity. They should bean integral part of all vegetable production systems, including plasticulture. While the effects of high wind speeds and soil abrasion are quickly evident, other less obvious reductions in yield and crop quality can result from wind stress at relatively low wind speeds. Wind protection systems, either artificial or vegetative, permanent or seasonal, offer benefits in improved microclimate for plant growth. Windbreaks enhance the soil warming and improve the water use efficiency characteristic of plasticulture. A better understanding of how shelter modifies crop growth will allow design of wind protection systems which achieve thedesired modification in microclimate and plant growth, while reducing the expense of windbreak establishment. A detailed review of windbreak technology is available (Brandle et al., 1988).

\section{Literature Cited}

Armbrust, D.V. 1984. Wind and sandblast injury to field crops: effect of plant age. Agron. J. 76:991-993

Bagley, W.T. and F.A. Gowen. 1960. Growth and fruiting of tomatoes and snap beans in the shelter areas of a windbreak. Proc. 5th World Forestry Congr. 3:1667-1670.

Bakker, J.C. 1988. Effects of humidity on growth and production of glasshouse cucumbers, tomatoes and sweet peppers. Acta Hort. 229: 159-163.

Baldwin, C.S. 1988. Theinfluence of field windbreaks on vegetable and speciality crops. Agriculture, Ecosystems, and Environment 22/23:191-203.

Bégin, S., J. Calandriello, and P.A. Dubé. 1994. Plasticulture R\&D in Quebec Region. Proc. Natl. Agr. Plastics Congr. 25:7-12.

Beste, C.E. 1986. Ryeand wheat control with fluazifop and sethoxydim for windbreaks. Proc. Western Soc. Weed Sci. 39:215-216.

Biddington, N.L. 1985. A review of mechanically induced stress in plants. Scientific Hort. 36:12-20.

Bilbro, J.D. and D.W. Fryrear. 1988. Annual herbaceous windbarriers for protecting crops and soils and managing snowfall. Agr. Ecosystems. Environ. 22/ 23:149-161.
Brown, H.W. and N.J. Rosenberg. 1972. Shelter effects on microclimate, growth and water use by irrigated sugar beets in the Great Plains. Agr. Meteorol. 9:241-263.

Brandle, J.R., D.L. Hintz, and J.W. Sturrock. 1988. Windbreak technology. Proc. Intl. Symp. Windbreak Technol., Lincoln, Neb. 23-27 June 1986. Elsevier, New York.

Brandle, J.R., L. Hodges, and J. Stuthman. 1995. Windbreaks and specialty crops for greater profits In: Agroforestry and sustainable systems: Symposium proceedings. USDA For. Serv. Gen. Tech.Rpt. RMGTR-261.

Brandle, J.R., B.B. Johnson, and T. Akeson. 1992. Field windbreaks: Are they economical? J. Production Agr. 5:393-398.

Bugg, R.L., F.L. Wäckers, K.E. Brunson, J.D. Dutcher, and S.C. Phatak. 1991. Cool-season cover crops relay intercropped with cantaloupe: influence on a generalist predator, Geocoris punctipes (Say) (Hemiptera:Lygaeidae). J. Econ. Entomol. 84:408416.

Bugg, R.L. 1992. Using cover crops to manage arthropods on truck farms. HortScience 27:741-745.

Claflin, L.E., D.L. Stuteville, and D.V. Armbrust. 1973. Wind-blown soil in the epidemiology of bacterial leaf spot of alfalfa and common blight of bean. Phytopathology 63:1417-1419.

Davis, J.E. and J.M. Norman. 1988. Effects of shelter on plant water use. Agr. Ecosystems Environ. 22/ 23:393-402.

Finch, S.J. 1988. Field windbreaks: Design criteria. Agr. Ecosystems Environ. 22/23:215-228.

Fryrear, D.W. and J.D. Downes. 1975a. Estimating seedling survival from wind erosion parameters. Trans. Amer. Soc. Agr. Eng. 18:888-891.

Fryrear, D.W. and J.D. Downes. 1975b. Consider the plantin planning wind erosion control systems. Trans. Amer. Soc. Agr. Eng. 18:1070-1072.

Foskett, R.L. 1955. Wind barriers increase vegetable yields. South Dakota Farm Home Res. 49:25-29

Grace, J. 1988. Plant response to wind. Agr. Ecosystems Environ. 22/23:71-88.

Harrison, D.J. and J.R. Chrimes. 1988. The effect of shelter on the yield, quality, and value of runner beans. Res. Dev. Agr. 5:53-58.

Hagen, L.J. and L. Lyles. 1985. Amount and nutrient content of particles produced by soil aggregate abrasion, p. 117-129 In: Erosion and soil productivity: Proceedings of the National Symposium on Erosion and Soil Productivity. Amer. Soc. Agr. Eng., St. Joseph, Mich.

Jaffe, M.J. 1976. Thigmomorphogenesis: a detailed characterization of the response of beans (Phaseolus 
vulgaris L.) to mechanical stimulation. Z. Pflanzenphysiol 77:437-453

Kahn, B.A., K.E. Conway, and C.G. Fisher. 1986. Effects of wirestem, wind injury, and iprodione on yields of six broccoli cultivars. HortScience21:11361139.

Lamont, W.J. 1993. Plastic mulches for the production of vegetable crops. HortTechnology 3:35-39.

Lanterman, W.S., D.T. Warholic, L.A. Ellerbrock, and P.J. Stachowski. 1985. Effects of fluazifop and barley windbreak competition on seeded onions in organic soil. Proc. Northeastern Weed Sci. Soc. 39:184-187.

Lin, W., J. Ailiang, and Z. Yi. 1987. On the effective protection distance of shelterbelt. Kexue Tangbao (Sci. Rpt.) 32:605-609.

Liptay, A. 1987. Field survival and establishment of tomato transplants of various age and size. Acta Hort. 220:203-209.

Lipton, W.J. 1970a. Growth of tomato plants and fruit production in high humidity and at high temperature. J. Amer. Soc. Hort. Sci. 95: 674-680.

Lipton, W.J. 1970b. Effects of high humidity and solar radiation on temperature and color of tomato fruits. J. Amer. Soc. Hort. Sci. 95: 680-684.

Makus, D.J. 1989. Field-grown European cucumber production-Use of windbreaks and 'mini' cultivars. Proc. Annu. Mtg. Arkansas State Hort. Soc. 109:3539.

Maredia, K.M., S.H. Gage, D.A. Landis, and J.M. Scriber. 1992. Habitat use and patterns by the sevenspotted lady beetle (Coleoptera: Coccinellidae) in a diverse agricultural landscape. Biol.Control 2:159165.

Michailides, T.J. and D.P. Morgan. 1993. Wind scab of french prune: symptomology and predisposition to preharvest and postharvest fungal decay. Plant Dis. 77:90-93.

Miller, D.R., W.T. Bagley, and N. Rosenberg. 1974. Microclimate modification with shelterbelts. J. Soil Water Conserv. 29:41-44.

Monette, S. and K.A. Stewart. 1987. The effect of a windbreak and mulch on the growth and yield of pepper (Capsicum annuum L.). Can. J. Plant Sci. 67:315-320.

NOAA. 1983. Climate atlas of the United States. Natl. Climate Data Center, Asheville, N.C.
Norton, R.L. 1988. Windbreaks: benefits to orchard and vineyard crops. Agr. Ecosystems Environ. 22/ 23:205-213.

Pasek, J.E 1988. Influence of wind and windbreaks on local dispersal of insects. Agr. Ecosystems Environ. 22/23:539-554

Phatak, S.C. 1992. An integrated sustainable vegetable production system. HortScience 27:738-741.

Pohronezhy, K., M. Hewitt, J. Infante, and L. Datnoff. 1992. Wind and wind-generated sand injury as factors in infection of pepper by Xanthomonas campestris pv vesicatoria. Plant Dis. 75:1036-1039.

Rosenberg, N.J., B.L. Blad, and S.B. Verma. 1983. Microclimate: The biological environment. Wiley, New York.

Simons, J.N. 1957. Effects of insecticides and physical barriers on field spread of pepper veinbanding mosaic virus. Phytopathology 47:139-145.

Sturrock, J.W. 1984. Horticulture: wind effects and shelter requirements, p. 53-69 In: Shelter research needs in relation to primary production: The report of the National Shelter Working Party, Wellington, N.Z. 1984. Water Soil Misc. Publ. 59.

Taksdal, G. 1992. Windbreak effects on the carrot crop. Acta Agr. Scand. 42:177-183.

VanGardingen, P. and J. Grace. 1991. Plants and wind. Adv. Bot. Rese. 18:189-253.

Waister, P.D. 1972a. Wind as a limitation on the growth and yield of strawberries. J. Hort. Sci. 47:411418.

Waister, P.D. 1972b. Wind damage in Horticultural Crops. Hort. Abstr. 42:609-615.

Winter, E.J. 1965. Some effects on wind upon vegetable crop plants. Scientia Hort. 17:53-60.

Wells, O.S. and J.B. Loy. 1993. Rowcovers and high tunnels enhance crop production in the northeastern United States. HortTechnology 3:92-95.

Woodruff, N.P., L. Lyles, L. Siddoway, and D.W. Fryrear. 1972. How to control wind erosion. USDAARS, Agr. Info. Bul. 354.

Zachar, D. 1982. Soil erosion. Elsevier, Amsterdam.

Zandstra, B.H. and D.D. Warncke. 1993. Interplanted barley and ryein carrots and onions. HortTechnology 3:214-218.

\section{Stand Establishment in Plasticulture Systems}

\section{Michael D. Orzolek ${ }^{1}$}

Additional index words. transplants, direct seeding, mechanization, plant population

Summary. Plasticulture enables growers to optimize establishment of vegetable and fruit crops under nonoptimum conditions and in locations with short growing seasons. Generally, warm-season crops such as muskmelon, pepper, and tomato, are established from transplants to decrease the time to maturity in the field. Directly seeding vegetables such as sweet corn, cucumber, and snap bean through plastic allows for optimum soil temperature and moisture to ensure maximum seed germination and subsequent seedling emergence. Mechanized transplanting or seeding of vegetables in plasticulture is available and successful if a firm, flat bed with plastic firmly stretched over the bed is formed and specific crop requirements are followed during establishment. Common mistakes made with plant establishment in plasticulture are discussed.

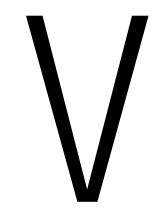
egetable crop production in the northeastern and mid-Atlantic Unites States in the early 1950s generally was limited by extremes in temperatureand moisture. The early efforts of Emery M. Emmert at the Univ. of Kentucky (Jones, 1994) demonstrated that plastic film, whether applied to the soil or covering a stationery structure, dramatically improved crop yields by maintaining more favorable soil temperatures and moisture. Since that early research by Emmert, environmental modification systems

'Department of Horticulture, The Pennsylvania State University.

The cost of publishing this paper was defrayed in part by the payment of page charges. Under postal regulations, this paper therefore must be hereby marked advertisement solely to indicate this fact. 